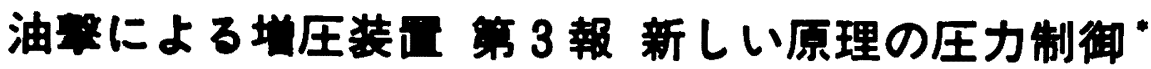

\author{
鉿木勝 正**
}

\section{A Hydraulic Pressure Intensifier using Oil Hammer 3rd Report-Pressure Control on a New Principle}

The author devised an intensifier using an oil hammer, and operated an oil cylinder at a pressure about six times that generated by a pump.

Operation of the intensifier as a pressure control device and its performance are discussed in this paper.

The pressure is controlled by switching on and off one solenoid controlled valve. The discrete value is controlled by the number of pulses for switching. The continuous value is controlled by the pulse width. Any value can be generated combining these two ways.

Theoretical results were found to be in close agreement with those determined experimentally.

The new device has the following advantages.

(1) Pressure is higher than the supply.

(2) Pressure can be easily controlled.

(3) Operation of the device has great repeatability.

(4) The supply flow is zero when you keep the output pressure constant.

\section{1. まえがき}

油举を利用する增圧装是を考案し”，一利用法として 油圧シリンタに用した。その結果, 油圧原の約 6 倍 の代力で袖压シリンタを取動するてとができ2)，てれ らの研究成果をすでに䢁告している.

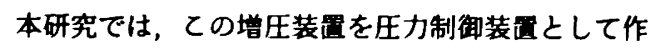
動させる方法を考案したので，その原理と性能を明ら かにする.

前述の油圧シリンタにおいて增圧する場合に，下流 端の電磁并を閉じ，管路中の定常流を急湤に止めて， 神擊を発生させると，1回でとに決まった値ずつ增圧 する. 従って電磁弁の開閉回数によって種々の大きさ の圧力を発生するてとができる，換言すれば，圧力の

\footnotetext{
* 昭和60年 9 月 4 日 原稿受付

**武藏工業大学機柣工学科
}

\section{離散値制衔が可能であろ.}

次に離散的圧力の中間の寀続值を得る手段として,

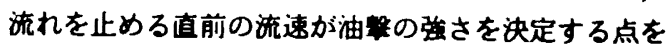

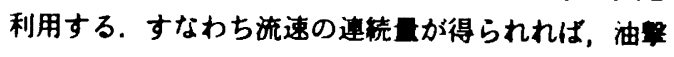

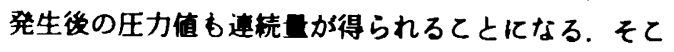
で，管内流速が電磁并の開放後に年から一定流速まで 加速されるととに注目し，電磁弁の開放時間を調節す ろととで，流速の加速基を制御することにした，従っ て、てれにより流速の連続値を得ることができ，油頢 により圧力の逴続値に変換できる。

本研究では，㫣碰并の開閉信号発生のためにマイコ ンを用い, キーボードからオンとオフの時間間隔およ

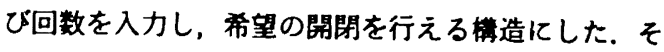
の結果，一つの龟碰弁の開閉によって，アナログ量の 增圧を行うシステムを単純な㭗造により棈成するとと ができた。 


\section{2. 主な町号と本实卧での数仙}

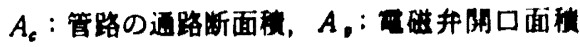
$\left(7.76 \times 10^{-6} \mathrm{~m}\right), c=\sqrt{K / \rho}:$ 作䐜油中の音速， $c$ 。 : 流是係数 $[0.6] ， D$ : 管路内径 $(5 \mathrm{~m})$ (Fig. 6 を除

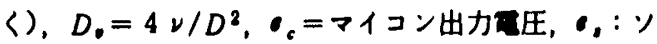

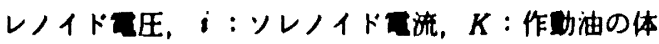
程强性係数 $(0.136 \mathrm{GN} / \mathrm{m}) ， L$ : 管路艮さ $(4.15 \mathrm{~m})$ ，

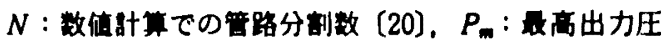
力, $P_{\mathrm{g}}:$ 供給压力 $(1.96 \mathrm{MPa}), p:$ 压力， $q:$ 流目,

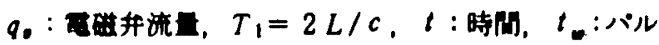
ス愒, $V$ : 圧力容器の容 $\left(6.3 \times 10^{-4} \mathrm{~m}\right)$ (Fig. 5 を 除く)，v：所面平均流速，w: 電碰井開度，y:スフ

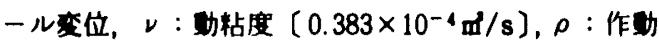
油密度 (853kg/m?

（注）添字 1〜3はFig.1の各部の值を示す.

\section{3. 装置篗成}

本研究の対象とする装国の篗成をFig.1亿示す，油 発生用管路の入口(1)に一定圧力の作轻神を供給し， 下流端(2に取り付けられた電磁并を開閉する。西磁并 開の状態で作勁油が管路内を高速で流れ，閉の時，油 加発生し，(2)加高圧になる。，その時，千ェック弁か 開き，作期油加吐出するので圧力容器内を压解する. ての時の吐出畺が条件によって明磪に決まっているの で，容器内が決まった值ずつ圧力上昇する．なお坏力 容器は，油注シリンタのモデルとして用いており，シ リンタ変位の無い場合のシリンタ室の片㑡をモデル化 している.てれは、ブレス機械の加圧行程の終段陼 または，クランブ装目でのクランブ中の增圧などを当 面想定している21。またシリンタ自荷か，ばね力のみ の場合にあ，シリンタ卒位等価的に作動神の圧樎 目に置き奐えるととによって，同様に考えるととがで きる.

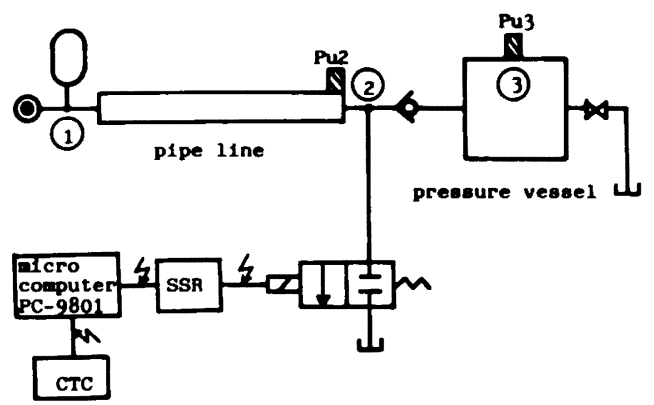

Fig. 1 Schematic diagram of the test rig

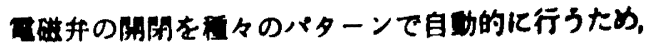

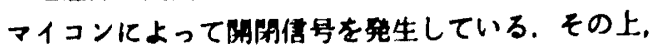
システムクロックをカウントするLSI (CTC = Coun-

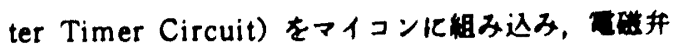

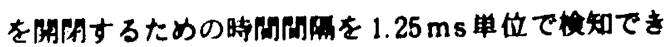
るように股定している. マイコンの传号をインタフェ 一スを介してッリッドステートリレー（SSR）飞送り，

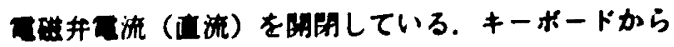
オンとオフの時问网的よひ回数を入力すると、プ クラムによって希里通りの斯作を行う。その結果，圧

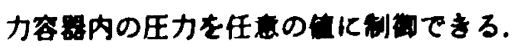

\section{4. 理䇶竍算}

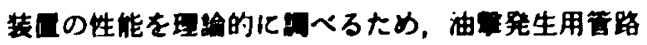

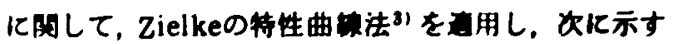

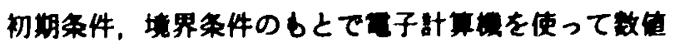
計算する.

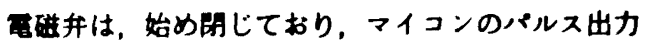

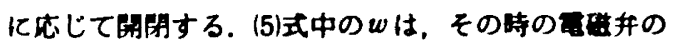
開度を表わし，0から1の值をとる。

チェック弁部では，(2)の圧力がチック并出口国(3) の圧力を越える埸合に，作野袖加とてを抵抗なく吐出 されるあのと仮定する，吐出された作㶭油により，圧

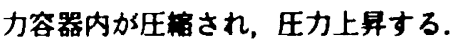

初期条件

$$
\begin{aligned}
& v=0 \\
& p=P,
\end{aligned}
$$

ただしり，pは管路内各点のそれぞれ断面平 均流速およひ压力を示す。

$$
p_{3}=P \text {, }
$$

境界条件

上流端

下流端

$$
\begin{aligned}
& p_{1}=P_{s} \\
& q_{0}=c_{0} A_{0} w \sqrt{\frac{2 p_{2}}{\rho}}
\end{aligned}
$$

$$
A_{c} v_{2}=q_{3}+q \text {. }
$$

チェック并の作用により

$$
\begin{aligned}
& p_{2}=p_{3}\left(q_{3}>0\right) \\
& q_{3}=0 \quad\left(p_{2}<p_{3}\right)
\end{aligned}
$$

圧力容器汇成し

$$
\frac{V}{K} \frac{d p_{3}}{d t}=q_{3}
$$

差分化して

$$
p_{3}=p_{30}+\frac{K \Delta t}{2 V}\left(q_{30}+q_{3}\right)
$$

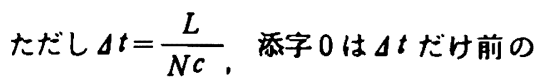




\section{時到の值を示す，}

\section{5. 实硢結果と計算結果}

Fig. 1 の装目において，压力容器内を袖压激の圧力 にはほ等しくしてから，磁并を閒的した。

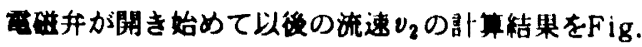
2 亿示す. 开加ら規則的借加し，100ms程度で，は ば一定流速に連する。そこでての流速变化をな考にし て，通当な時間間隔で西磁并を閒する。

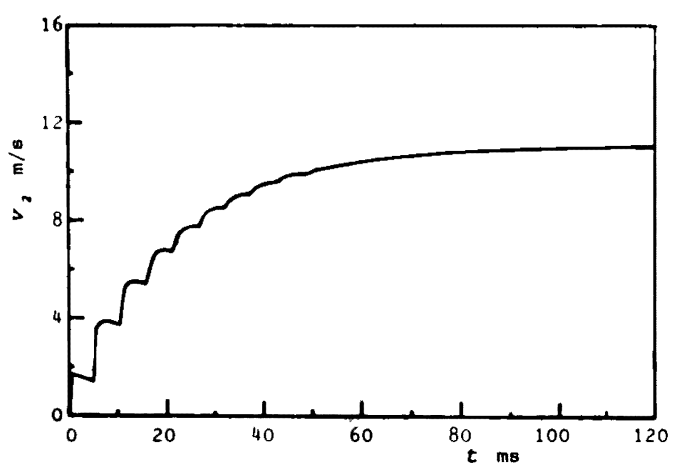

Fig. $2 v_{2}$ after valve opening

電碦弁のスプールに差動トランスを付け，スプール

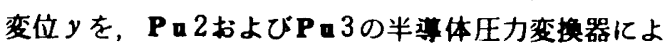
り圧力 $p_{2} ， p_{3}$ をそれぞれ検出した.これらの信号およ びマイコンの出力電压 $e_{c}$, 電磁弁ンレノイド電圧 $e_{s}$, 同電流 $i$ をす信号をそれぞれディジタル式記愔装置 （トランジントコンバータ）に一時記境させた後， $X Y$ レコータにより記録した.

\section{1 圧力の教散傎制御}

最初に，流速が十分一定になってから電磁弁を閉じ るために，パルス幅を125msにして開閉した．Fig. 3 (a)にこの時のマイコン信号と各部の応答を時間轴を共 通にして表示した. マイコン信号のオンから，22.1 $\mathrm{ms}$ 幄れて電碰并が開き始め，管路下流端圧力 $p_{2}$ がほ ぼ零になるので，管路内作動油加速される。電磁并 の閉銷により $p_{2}$ は急敬に上昇し，以後減哀振動してい ろ. 乙の上昇時の作動油の吐出により, 容器内圧力 $p_{3}$ あ上昇した後，次の油擊が発生するまで一定に保たれ ている.
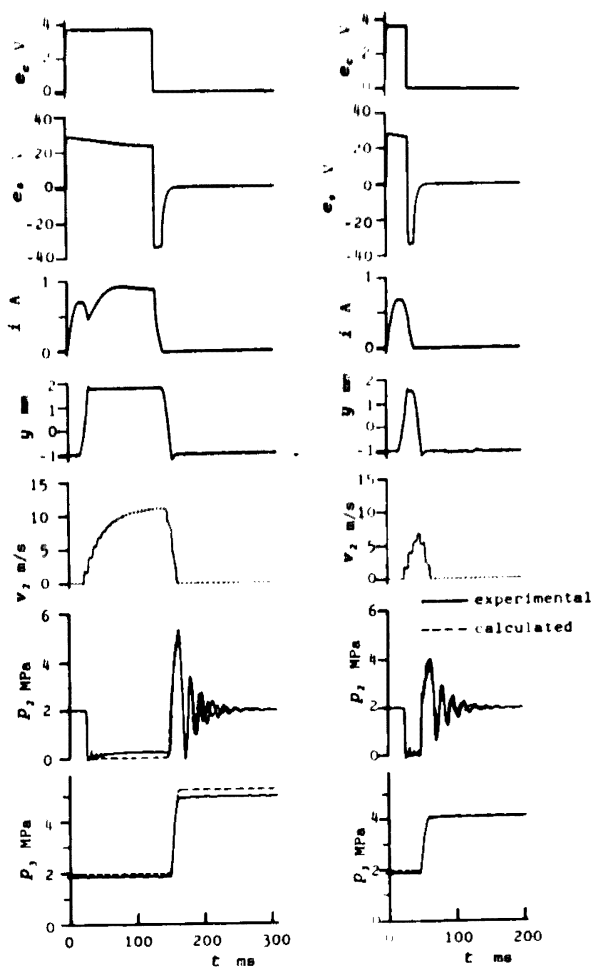

(e) $\mathrm{t}_{0} .125 \mathrm{me}$

Fig. 3 Responses of the system to pulse input with different width

次に電碰并の開閉を継続するか，1回の開閉でとに 決まった圧力上昇が得られる．Fig. 4 は電磁并の開閒 回数すなわちバルス数 $j$ と容器内圧力 $p_{3}$ の同係を示 している. ただし、デューティ比は50\%である. 破線 は $j=16$ の場合の計算結果を示す. 他の $j$ 亿対する計 算結果を省略しているが，途中まで全く同じ圧力㚆化 をする．実験結果です，開閉でとの圧力が互いに同じ 値を示している. jの增加行従って圧力上昇するか， やがてある圧力で飽和する．乙の飽和圧力を最高出力 理力 $P_{m}$ とする. 乙の場合の実検結果の最高出力圧力 は14.3MPaであった。なお，ての時の 1 回ごとの政力 上昇および最高出力圧力を数值計算とは別㐾，解析的 にも求めており, その結果によれば, 最高出力圧力 $P_{m}$ は次式で示される゙2.

$$
P_{m}=\frac{c D^{2} P_{s}}{32 \nu L}\left(1+2 \sqrt{\frac{D_{1} T_{1}}{\pi}}+D_{\bullet} T_{1}\right)
$$




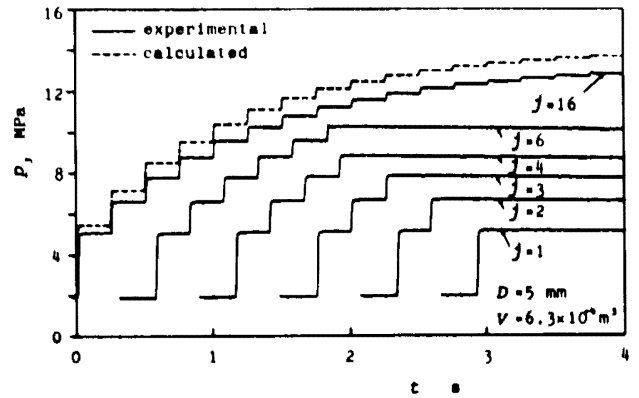

Fig. 4 Pressure $p_{3}$ versus number of pulse $/$ (1)

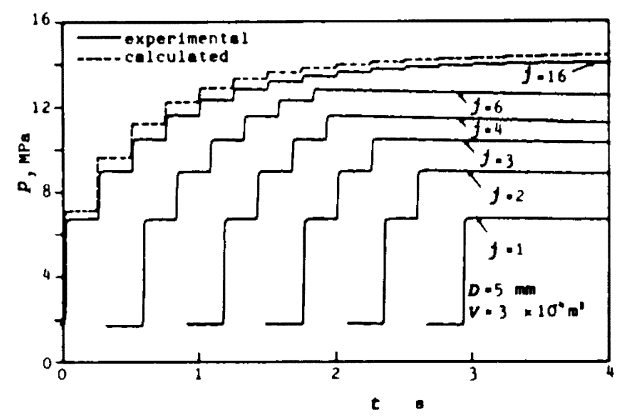

Fig. 5 Pressure $p_{3}$ versus number of pulse $j$ (2)

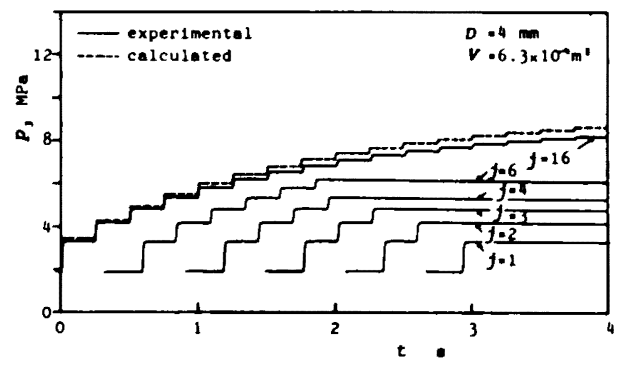

Fig. 6 Pressure $p_{3}$ versus number of pulse $j$ (3)

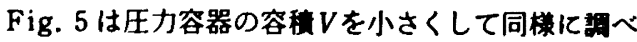
た結果を示す. Fig. 4 の結果に比校して, 同じjの值 に対する圧力か高い，しかし最高出力圧力は等しくな っている。

Fig. 6はFig. 4亿比校して管路内径 $D$ を小くして 調べた結果を示す．同じ $j$ の值佂対する圧力および最 高出力圧力がいずれる低くなっている，ただし，ての 場合には管路への供給流量が減少するてとにも留意す べきである゙'。

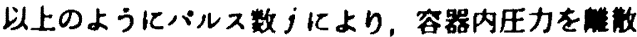

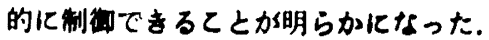

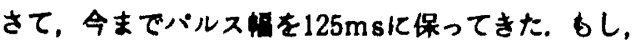

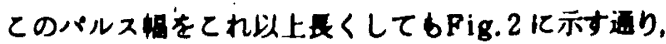
流遇ははとんど变らない，従ってjと仕力 $p_{3}$ の成係に

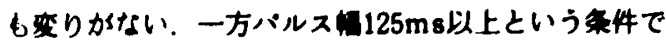
あれば，手娌によって磁并园流を容易にオンオフで

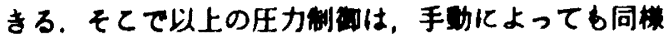
に行えるという特艮を持っている。

\section{2 圧力の速楼倠制}

前節の方法では得られる圧力は敉的でる。 そて

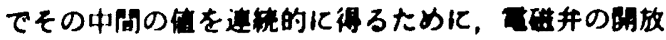

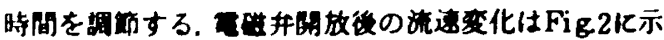

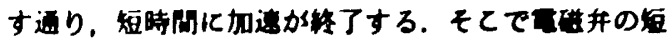

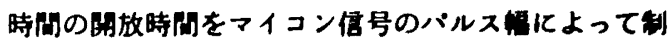
御する. Fig. 3(a)，(b)にはパルス的がそれそれ125ms と $30 \mathrm{~ms}$ の姆合のマイコン倍号と各部の纯夻の俰を示 している，パルス幅加短くなると、マイコン信号とス

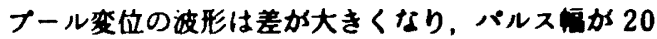

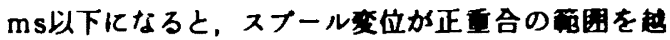

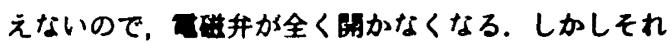

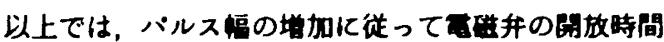
あ単調に增加する。.そこで開放時間の增加に従って, 油慗による圧力上界も增大する。

Fig. 7にパルス愊 $t$ 。と得られる氏力 $p_{3}$ の成保を示 す. 実缐と白丸印は，パルス1個の埸合のそれぞれ，

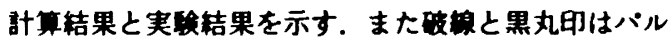
スを2 個発生させた場合を示し，1固目のパルスのを 前節と同じ $125 \mathrm{~ms}$ 江固定し， $125 \mathrm{~ms}$ s後に2 個目をパル

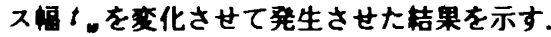

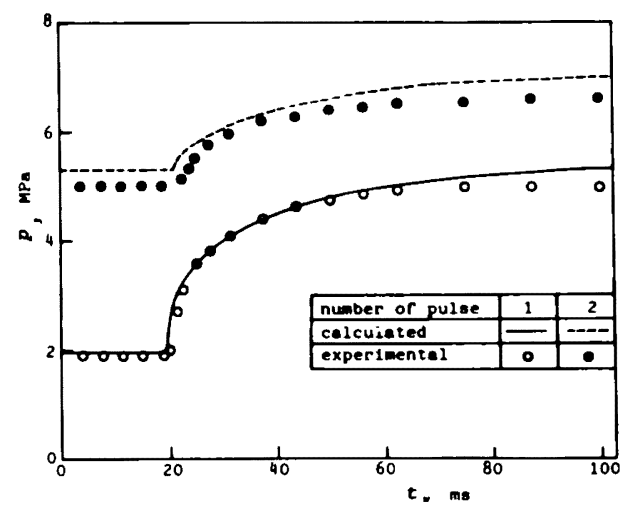

Fig. 7 Pressure $p_{3}$ versus pulse width $t_{\mathrm{w}}$. In case of two pulses, the first pulse width is $125 \mathrm{~ms}$ and the second one is $t_{\mathbf{w}}$. 


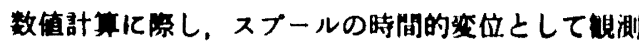
した波形を折れ線で近似して用いている，叟娩結果は

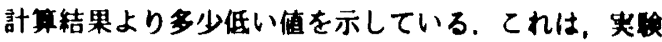

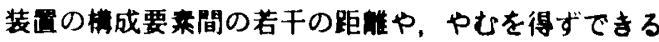

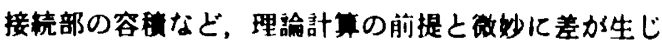
ているととに起因するすのと思われる.

以上のように信号のバルス甶によって，纴力を連桡 的に制御できるととを理論，実梌両面より明らかにし

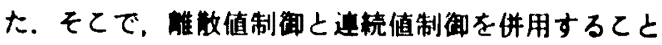
により，供給圧力加影高出力圧力の筑囲内で，任意 の珐力值を発生できることになった。

\section{3 再珯性}

Fig. 8は再現性を調べるため，同じ実涘を5回繶け て行った結果を示す.それぞれバルスを2個発生させ， 初のパルス幅を $125 \mathrm{~ms}$ ，二番目のパルス愊を $30 \mathrm{~ms}$ としていろ. 5 回ともはとんど同じ結果が得られてい ろ.とのことは，乙の装貫を圧力制御装置として利用 する場合に高い信頼性が得られるてとを示している。

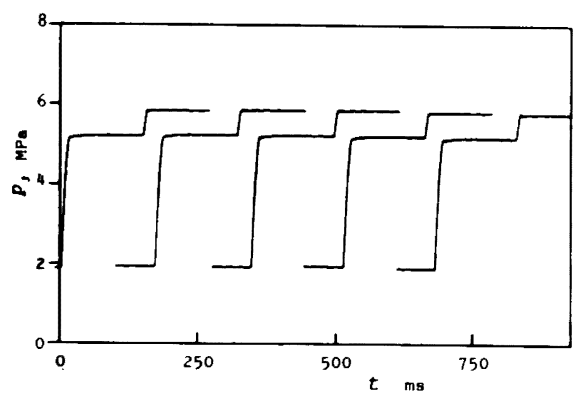

Fig. 8 Five tests to illustrate the repeatability of experimental results

再現性の良い理由は次の通りである．一般の圧力制 御の方式が、スプール并，ポペット并などの制御オリ フィス部の微小な流路面皘すなわち流路抵抗を変化さ せて，圧力制御するてとを基本にしているのに対して， 本装置は油撃現象の規則性を圧力制御に利用している。

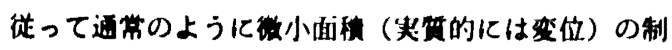
御を必要としないので高い再現性を有し，ゴミに対し ても强い。

\section{6. あとがき}

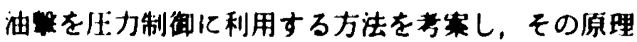
と特性を明らかにした，特艮をまとめると以下の通り である.

(1) 油圧源よりる高い珐力を毠生する。

(ii) DA コンバータ，アナログ回路などを必要とせず，

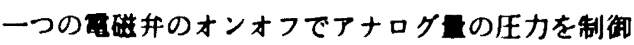
できる，従って電気系統が単純で，特にマイコンな どで圧力を制御する埸合に有利である。

(iii) 油現象の規則性を圧力制御に利用しているので 高い再現性を有し，ゴミに対しても強い．

(iv)一定圧力を保持する場合には，電磁并を閉じてお けばよいので，その時の本装国への供給流醍が尔に なる.

おわりに，本研究に峦し御支嗳いただいた本学佐藕 三禄教授，実験に御協力いただいた小林邦夫助手およ び卒研生に深謝します。また本研究は，財団法人油空 圧機器技術振興財団研究助成金の援助を受けているて とを記して，関係者に謝意を表します。

\section{考文献}

1）跉木勝正：油繁江よる增圧装置 第 1 報 基本的 特性, 油圧之空気圧, 13-6，417/425（昭579)

2）跉木勝正：油撃による增圧装䈯 第 2 報 油圧 リンダへの応用, 油圧と空気圧, 16-3，191／ 197 (昭60-5)

3) W. Zielke: Frequency-Dependent Friction in Transient Pipe Flow, Trans. ASME, Ser. D, 90-1, 109/115 (1968) 